\title{
Identity, race and faith: The role of faith in post-Apartheid South Africa
}

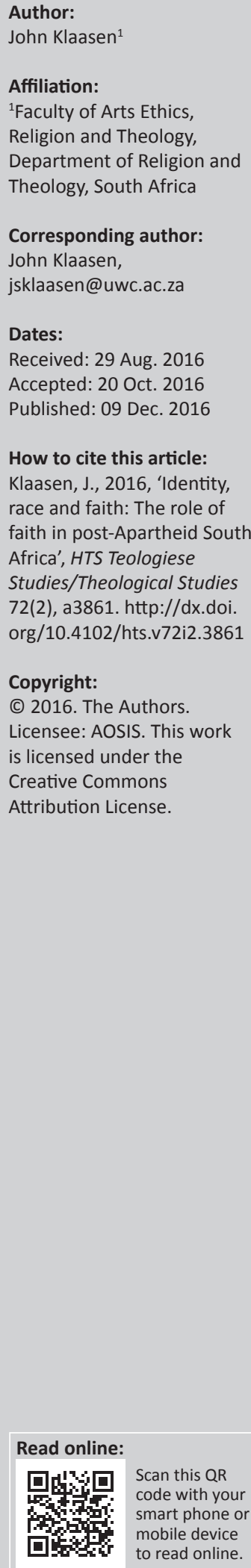

South Africa has experienced an unprecedented influx of migrants in the 21st century. Immigration and race have contributed to the raising of important questions of identity and social inclusion. Immigration and race are two crucial phenomena for the church in South Africa because the overwhelming majority of immigrants to South Africa are affiliated to Christianity and active participants in worshipping communities.

This article is an attempt to critically engage with the complex phenomena of immigration and race for the role of Christianity in identity. I will attempt to show how mainstream Christianity as an open-ended narrative and can provide the space for creative tension between the 'host' and 'stranger' for identity formation. I will use the theoretical framework of Don Browning's correlational approach to demonstrate how the experience of immigrants and minority race groups creates identity of self and the constructive other.

\section{Introduction}

Identity is one of the most pressing topics confronting the 21st century global community. A global community characterised by national, regional and transnational migration must take the fluidity, hybridity and multiplicity of the once homogeneous human community serious. Homogeneity is now threatened by the redefining of once clear and definite borders and frameworks of being. The biggest threat to identity is migration of people across borders and the racial distinctions and consciousness that such migration accompanies. Alcoff asserts:

There is considerable interest in the question of identity today, perhaps equalled only by the considerable confusion around the question of why identities continue to exert such power, and whether they should be acknowledged and legally recognized or simply ignored in the hope that they will disappear. (2003:1)

This paper is an attempt to demonstrate the complexity of identity in light of the widely acclaimed peaceful transition of the South African nation from a racialist to a democratic nation. I will also demonstrate that faith plays a role in the formation of identity and that faith creates the space for cohesive coexistence. The Christian faith, when viewed as narrative, creates space and time for perceived differences and alienations to coexist. Within narrative, experience is central to the hermeneutical interpretation. I will further demonstrate that Christian faith plays a role in the authenticity of the experience. The theoretical framework draws on the approach of Browning's approach of practical theology. Browning's approach is a correlation of theory and practice and is named practice, theory and practice.

\section{Identity within the South African context}

Immigration is coupled with race. In Britain, the main colonial power of South Africa, immigration has been equated with race. Isiortho concludes that immigration has even become the coded term for race:

So did immigration become synonymous with the Black presence in UK society? According to commonsense perceptions of nationhood, there was a 'race' problem in the UK which was linked to unrestricted immigration. 'Race' was not mentioned but immigration was and it was the same thing as Black immigration. Thus immigration was a coded term for talking about 'race' related issues. (2009:296)

In 1965, immigration legislation was based on race relations until the 1980's when the Swann report promoted multiculturism. In the early 21st-century secure borders, Safe Haven promoted a 'common sense of nationhood'. This implied that Britain should move away from a nation of communities to a nation of citizens with a shared value system (Schain 2010:213). The question of race and its relation with immigration in Britain could be seen parallel with South Africa, its former colony and a microcosm of the identity question in Europe although identity on the basis

Note: This article is published in the section Practical Theology of the Society for Practical Theology in South Africa 
of colour takes on a different perspective in Britain and other parts of Europe. In the 1960s, South Africa was characterised by institutionalised racism; in the 1980s, there was a strong call by the banned liberation movements for a sense of a common nationhood; in the 21st century, the grassroots movements for multiculturism are growing steadily.

Race remains a contested term and is commonly acceptable. There are those acclaimed philosophers who reject the existence of races (Appiah 1992:45). However as Du Bois reminds that, 'in our calmer moments we must acknowledge that human beings are divided into races'. He however also claims: 'When we thus come to inquire into the essential difference of races we find it hard to come at once to any definite conclusion' (2003:43). Despite the problematic nature of the term and its meaning, there is a large corpus of empirical evidence that race is closely associated with identity.

Immigrants have increased from 4835 in 2001 to 6545 in 2002. However, in 2003, there has been a 39\% increase and in 2013 there are about 142800 documented 'foreigners' ('individuals who are not citizens') in South Africa out of a population of 51770560 million people. More than half (55.4\%) of the immigrants are from other parts of Africa (SouthAfrica.info n.d.; Statistics South Africa n.d.). ${ }^{1}$ The number of immigrants to South Africa is estimated to be up to 9 million (Consortium for Refugees and Migrants in South Africa 2008b). One might question the importance of immigration in the quest for identity if the majority of immigrants are African and share a common history and geography. One might also find support for such sceptism in light of the attempt by the former president of South Africa, Thabo Mbeki, for an African Renaissance.

Mbeki's vision for an African Renaissance was twofold. On the one hand, he wanted to redefine Africa independently of the colonial past and on the other hand, put Africa to the world for what it really is; the origins of the human race. While there is significant support for the broad vision of an African identity independent from colonial rule, the absence of open honest dialogue within the hegemony of African stifles the African identity.

Within Mbeki's notion of African Renaissance is the absence of gender oppression, the vibrancy of 'hybridity, heterogeneity, otherness, difference' that signifies a new African identity and fetish, which 'inserts ambiguity into the midst of hegemony and which does so both through image and act' (Cochrane 2009:21-24). These three ambiguities in Mbeki's African Renaissance, with its rigidity, fixed boundaries and antagonism towards difference, attest to the lack of space for engaged particularity within the scope of African Renaissance. While there is significant support for the broad vision of an African identity independent from

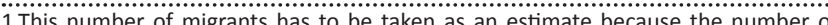
migrants to South Africa between 1994 and 2001 ranges betwe 2.5 million and 5.0 million. Houthever, the bumber of migran 2001 ranges between 2.5 milion and 5.0 million. However, the number of migrants from South Africa exceeds 5.0 million (it is estimated to be up to 9.0 million) (Consortium for Refugees and Migrants in South Africa 2008b) colonial rule, there is no space for creative tension amongst differences, otherness, foreignness and strangeness within African Renaissance. Cochrane raises the possibility that fetish 'points to identities which embrace a Renaissance of a different kind, not yet recognised, but maybe present in sublimated form in the burgeoning Pentecostal churches that increasingly pervade the African landscape, and beyond' (2009:25). It is my aim to add to the discourse of discovering identity beyond the rigidity and boundary bound specificity. My contention is that Christian faith plays a role by affirming and expanding the identity through dialogue with the stranger.

South Africa is at the brink of social disintegration because of the retreat to identities that is relative and the absence of dialogical construction of identity:

Despite the peaceful transition from separate development to democracy and the coexistence of religions, there have been episodes of conflict that threatened the fragile social cohesion of the South African nation. In many ways immigration has resulted in - or at least contributed to conflict. Many violent confrontations can be attributed to foreign cultural and social practices are not completely separated from religious practices, beliefs or persuasions. (Klaasen 2015:2-3)

Both race and immigration have contributed to the fragile cohesion of the South African society. In this regard, the xenophobic attacks of 2008 in Johannesburg and Cape Town and the recent racist outbursts by influential persons, including the legal fraternity, attest to the fragile cohere society.

Immigration has been the result of scientific innovation, expansion of territory, conflict, poverty and globalisation. Within the South African context, with its complex political history, immigration and race are two indispensable phenomena in the quest to make sense of identity. This does not mean that identity is limited to race and immigration nor that identity is a social enclave characterised by the colour of one's skin or national orientation. It does mean that these two phenomena form an integral part of identity.

Any quest for identity must take seriously that race defined 'society' prior to 1994. During the 1990s new 'shared every day and institutional practices across its racial segmentations, cautiously rallying around an incipient nationalism, shared icons and experiences' (Hansen, Jeannerat \& Sadouni 2009:188). It is within this quest for identity that the Christian narrative can play a role by assuming that 'Human experience is the starting point and the ending point of the hermeneutical circle' (Radford Ruether 1983:12).

\section{Narrative}

Narrative as a process of invitation, enrichment and transformation takes seriously the other as a conscious self. Narrative is constant because it has sequence and consistency, yet it is open to additions. In an attempt to take seriously the constancy and the openness of narrative, I define narrative as: 
open-ended, inviting, enriching and creating through both commonalities and differences ... it is inductive and through critical engagement and dialogue (by movement) gives a new interpretation of community, tradition (non-rational symbol) and experience (reflected experience) as its core facets. (Klaasen 2015:6-7)

An open-ended narrative invites critical engagement and dialogue on the experience of the affected people in relation to Transcendence or God. Identity, from the perspective of an open-ended narrative, is more than the sum of my story. It includes other stories in which I am one of the characters, yet not an irrelevant one. 'My story is embedded in family histories and in the histories of a city and a country; my story is part of our story' (Van der Merwe \& Gobodo-Madikizela 2007:4). This does not mean that identity is arbitrary or ambiguous, nor that identity is rigid or fixed:

Ricoeur distinguishers between abstract, formal identity (idem) and dynamic identity (ipse). The former refers to that which is always the same and the latter to the constant in a diverse of circumstances. Dynamic identity includes change, difference, to evolve within a constant pattern of one's life. (Van der Merwe \& Gobodo-Madikizela 2007:2-3)

There is another element to narrative that informs identity. Taylor refers to Heidegger's Being and Time as a description of the self as a temporal being in the world. Present identity or self is constituted from what I have become to a sense of what I am heading to (ekstaseis). Identity is about 'growing and becoming' (1992:50). Sonn (2010), in narrating his own story as a formerly classified 'coloured', claims that immigration is about:

uprooting and subsequently reconstructing lives in a new social, cultural and political context-one with a different racial formation and history of power relations....and new opportunities for identity making, participation and belonging. (p. 433)

... religious practice and ethics produce a sense of belonging to a community, a sense of personal dignity and a claim to respect and recognition as a 'proper' person by the surrounding society. (Hansen et al. 2009:193)

The Christian faith assumes that identity is meaningful within the contours of the narrative, specifically the story of the person of Jesus Christ. It is a story of Jesus's birth, ministry, death and resurrection. The story of Jesus Christ is not a closed story that is limited to our interpretation or the interpretation of any tradition. It is a story that is connected with the story of the Israelites and that of the Christian church. It is a story that encapsulates the past, present and future. The Christian story as open-ended is not closed to other stories, such as the story of culture or society. Christians belong to different communities with different stories.

The Christian story is not restricted to a specific language or closed symbols. Language is not about disembodied rules or parts of the whole, but it is a symbol (non-rational) that speaks with reason of the heart (Klaasen 2012:114). With regard to symbols, Gill claims that they are a tool of hermeneutics because it questions the perceived reality of the 'in-group'. Symbols also invite participation and transform the enclavement of both groups into what it means to be created in the image of God (1996:126-128). The other is not a threat to my identity but becomes a significant other (Habermas borrows this phrase from George Herbert Mead) that makes up my own identity by interacting through language (Taylor 1992:509).

Narrative is not restricted to the writing or narrated modes of plots or dramas, but the story is the identity of a person(s). To tell a narrative of a person is not just transmitting information, as powerful as that may be, but it is also a mode of being in the presence of others. The telling of a story is living life in the company of others. It is a way of being before it is a mode of giving. The story is integral to the identity of the person.

Immigrants or different race groups within the South African context is not the other in a sense of alien or disengaged entity or strangers. According to Hansen et al. (2009):

In classical social theory the figure of 'the stranger' is defined as both fascinating and unnerving because he/she upsets and ruptures the flow of the ordinary and tacit assumptions that make it possible for everyday life to cohere and reproduce itself. (p. 188)

The other, disengaged, alien and stranger, within the Christian narrative, is the significant other. The Christian story, which has significantly influenced the cultural and social contexts of South Africa, places the significant other as constitutive of the identity of selves when viewed as openended narrative. The significant is not self-consciousness as in the case of Locke and Hume (self-awareness), but it is closer to MacIntyre's 'quest' for life (Taylor 1992:48-49). This 'quest' for life spans over time and penetrates space. It encounters different selves that add value to who I am becoming.

The Christian narrative provides the community that forms the locus for the self to become. The community is not a collection of isolated atomistic individuals but selves in constructive dialogue. The community is made up of selves who are innovative, creative and processural. The selves are symbiotic and their living relationships create living beings that are active in formation of life as a whole and not life as fragmented episodes.

\section{Practice, theory, practice and theory ${ }^{2}$}

Browning's critical correlation of practice, theory and practice, which is a break away from Tillich's theory-practicedichotomy, forms the theoretical framework of the application of race and immigration to identity. Like Browning, I also use praxis as the starting point of the hermeneutical circle. The practice refers to experience. I add one more stage to Browning's correlation, however. The fourth stage is theory.

2.This model was previously described, but not applied. I am applying the model of Browning with my additions to his three-pronged stage. I add another stage to experiences. 
In the first stage, the 'human experience' (as used by Radford Ruether and later Ackermann) of the immigrants and minority race groups who are regarded as 'the other' are taken seriously. Ackermann does not discriminate against or give preference for any kind of experience, but is inclusive in her notion of experience (2008:40). The experiences are taken as authentic and independent from theoretical enslavement. Narrative becomes a constructive way of engaging with the experiences of the affected persons because the authenticity of the experiences does not depend on the abstract theoretical formulation of what is experience, but on the degree of being of the persons.

Within this stage, symbols and metaphors are taken as core means of communication. Immigrants and minority race groups are not limited by language but give expression through symbols and gestures that transmit feelings and reason (although in non-rational and not irrational form). This stage is symptomatic of the post-foundationalist approach, which is 'reflective and situational embedded in epistemology and methodology' (Muller 2011:3). The group in the centre listens to the narratives of the group on the margins (Davie 2004). The worship of the Christian community, which is interactive, formative and social, provides the context for such expressions of experiences. Worship is about a meta-narrative that is open to other narratives. Symbols and metaphors of the immigrants and minority race groups are placed within the transformative power of the Christian symbols.

The second stage has a direct bearing on the first stage. In this stage, an attempt is made to make sense of the human experiences. What tools are at our disposal to engage with the experiences and to interpret the experiences for what it is? A step is taken back from the experience and it is viewed from a more abstract and objective point of view. We do not use technical reason, but rather reasoning that interacts with experiences or engaged reasoning that uses hermeneutical tools with space for the interpreter. Here is a direct link between object and subject. In this stage the interpreter is cautious not to:

reduce experience to theory as Tracy and Browning do in the application of the theory-laden phase. Whist I agree that theory and practice are closely associated, I allow more distance between the two. (Klaasen 2014:11-12)

In this stage, the immigrant or minority race group is not isolated. Their experiences are important for the sensemaking stage. Continuous interaction between the different facets of the hermeneutical tools makes this stage effective in the attempt to interpret the experiences. The Christian community as a spirit-filled community is made up of persons with different gifts and these gifts are used to make sense of the current reality in the face of uncertainty and ambiguity. The Christian community creates the space for the interaction between the tools of the selves and the constructed other. Within this community, theological language is not so much: a kind of scientific describer of some object, which we contemplate ... It, is exhortative, dramatic, performative language of symbolic action. It comes from worship and prayer. Religious language is the professing and confessing of people pressing for a more complete publicity. (Everett 1988:162)

The third stage is about the experience that has undergone changes in view of the engagement with the tools of hermeneutics. In this stage, we move beyond the 'what is the experience' to 'what ought the experience to be'. A distinction is made between appropriate and non-appropriate, right and wrong, good and bad. This stage is about setting norms for the formation of whole beings. Experiences are evaluated and influenced so that persons are valued as the image of God. Experiences become transformed experiences. Experiences do not have to remain the same, but through dialogical encounters move beyond the constraints of particularity.

The Eucharist is one example of transformation through participation. The worshipper is transformed through the participation in the memorial meal of Jesus Christ. The act of penance in the Anglican liturgy is an acknowledgement that worshippers are in need of transformation. The absolution transform the worshipper into a new being who can glorify God as a free person.

Active participation in the Eucharist is a basic right that underlines other rights such as basic human rights and rights to information. The Eucharist provides the space for honest open dialogue that goes beyond limited space of the participants in the Eucharist. Everett describes participation by two religious sacraments. Firstly, profession is the proclamation of salvation and our entry into salvation. Profession is our rejection of the negative imaginations and perceptions and the affirmation of the possibilities given to all humanity by the grace of God (1988:159-166). Secondly, confirmation is the act of confirming each other as equal participants in an interdependent relationship (1988:166).

The fourth stage consists of the sense-making of the transformed experiences. In this stage, the Christian tradition and other disciplines apart from theology become hermeneutical tools. Traditum, the Latin for tradition, refers to the mode of transmission. Tradition is taken seriously for the past, the present and the future. According to Klaasen (2013):

On the one hand tradition is about shared history with events, persons and periods and, on the other, bringing deeper meanings to these aspects that form part of tradition through reason. (p. 114)

Theology engages effectively with other disciplines such as philosophy, sociology, anthropology, politics, economics and psychology. Browning's use of an interdisciplinary approach goes back to his doctoral thesis of the 1960s. He has used disciplines such as psychotherapy to correlate with theology to deepen the findings of both theological processes and that of other disciplines (Hestenes 2012:3). Consequently, the task 
of (practical) theology goes beyond the care for the church (Browning 1985:16; 1991:57). Within this perspective of care, the Christian community dialogue with other communities forms different traditions. This is one of the strengths of Browning's interdisciplinary approach. There is a room for difference, for the other and for diversity. The other can include race, age, nationality, religious and the ones on the periphery.

The Anglican liturgy illustrates the transformation of the confessing sinner entering the worship and then leaving worship with the commitment:

Father almighty we offer ourselves to you as a living sacrifice in Jesus Christ our Lord. Send us into the world in the power of the Holy Spirit to live and work to your praise and glory. (1989:129)

Immigrants and minority race groups share in a common Christian story with the rest of the participants and all become fully engaged in the growing and forming identities.

\section{Conclusion}

Identity is not static but dynamic. Identity is about formation and growing into the potential image of God. Immigrants and minority race groups do not threaten the existence of the group in the centre but is significant others, who form an integral part of the process of becoming in the image of God. The Christian narrative as an open-ended story is the space to draw the other, the stranger and the alien into a creative tension.

Experience transcended origin or race so that transformed experience lead to identity that is not bound within the confines of the static. Human experience within the correlation approach of Browning leads to identity as becoming and forming for all partners within this openended Christian narrative.

\section{Acknowledgements Competing interests}

The author declares that he has no financial or personal relationships which may have inappropriately influenced him in writing this article.

\section{References}

Ackermann, D., 2008, 'Rosemary Radford Ruether: Themes from a feminist liberation story', Scriptura, 37-46.

Alcoff, L.M., 2003 'Identities: Modern and postmodern', in L.M. Alcoff \& E. Mendieta (eds.), Identities: Race, class, gender and nationality, pp. 1-8, Blackwell Publishing Ltd, Oxford.

Anglican prayer book, 1989, Anglican Church of Southern Africa, Harper Collins Publishers, Jeppestown.

Appiah, K., 1992, The illusions of race, In my father's house: Africa in the philosophy of culture, Oxford University Press, New York.

Browning, D.S., 1985, 'Practical theology and political theology', Theology Today 42(1), 15-33. http://dx.doi.org/10.1177/004057368504200104

Browning, D.S., 1991, A fundamental practical theology, Fortress Press, Minneapolis, MN.

Cochrane, J.C., 2009, 'On identity and faith in the global political economy', Journal of Theology for Southern Africa 134, 14-31.

Davie, G., 2004, 'Creating an agenda in the sociology of religion: Common sources/ different pathways', Sociology of Religion 65, 4323-4340. http://dx.doi. org $/ 10.2307 / 3712317$

Du Bois, W.E.B., 2003, 'The conservation of races', in L.M. Alcoff \& E. Mendieta (eds.), Identities: Race, class, gender and nationality, pp. 43-48, Blackwell Publishing Ltd, Oxford

Everett, W.J., 1988, God's federal republic: Reconstructing our governing symbol, Paulist Press, New York.

Gill, R. (ed.), 1996, Theology and sociology: A reader, Cassell, London.

Hansen, T.B., Jeannerat, C. \& Sadouni, S., 2009, 'Introduction: Portable spirits and itinerant people: Religion and migration in South Africa in a comparative perspective', African Studies 68, 187-196. http://dx.doi.org/10.1080/ 00020180903109565

Hestenes, M., 2012, 'The early browning: Pastoral care in a pluralistic age and the method of practical moral inquiry', HTS Theolgical Studies 68(2), 1-7, http://dx. doi.org/10.4102/hts.v68i2.1211

Isiortho, D., 2009, 'Black identities and faith adherence: Social policy and penal substitution in the epoch of the SS Empire Windrush', Black Theology: An International Journal 7(3), 282-299.

Klaasen, J., 2012, 'Open-ended narrative and moral formation', Acta Theologica 32(2), 103-124.

Klaasen, J., 2013, 'The interplay between theology and development', Missionalia 41(2), 182-194.

Klaasen, J., 2014, 'Towards an approach to development as mission: The category of personhood as addressed by Amartya Sen', Missionalia 42(1-2), 72-78.

Klaasen, J., 2015, 'The missionary role of mainstream Christianity: Towards a narrative paradigm for social integration of minorities in pluralistic post-apartheid South Africa', HTS Theological Studies 71(2), Art. \#2115, 1-9. http://dx.doi.org/10.4102/ hts.v71i2.2115

Müller, J.C., 2011, 'Postfoundational practical theology for the time of transition', HTS Theological Studies 67(1), 1-5, http://dx.doi.org/10.4102/hts.v67i1.837

Radford Ruether, R., 1983, Sexism and God-talk: Toward a feminist theology, SCM Press, London.

Schain, M.A., 2010, 'Managing difference: Immigrant integration policy in France, Britain, and the United States', Social Research 77(1 Spring), 205-236.

Sonn, C.C., 2010, 'Engaging with the Apartheid archive project: Voices from the South African diaspora in Australia', South African Journal of Psychology 40(4), 432-442. http://dx.doi.org/10.1177/008124631004000406

SouthAfrica.info, n.d. Homepage, viewed n.d. from http://www.southafrica.info, 2012. STATS SA, http://www.statssa.gov.za/Publications/Po30142011, 23 September 2013.

Taylor, C., 1992, Sources of the self: The making of the modern identity, Cambridge University Press, Cambridge.

Van der Merwe, C. \& Gobodo-Madikizela, P., 2007, Narrating our healing: Perspectives on working through trauma, Cambridge Scholars Publishing, New Castle. 